\title{
Characterization and Classification of Soils of Askate Sub-watershed, South Wollo Zone, Northeastern Ethiopia
}

\author{
Mulugeta Tufa ${ }^{*}$ Tadla Guadie Kefyalew Tilahun Mulugeta Fiseha Seid Ahmed \\ Department of Natural Resource Management, College of Agriculture and Natural Resource, Mekdela Amba \\ university, P.O. Box 32, Tulu Awuliya, Ethiopia
}

\begin{abstract}
Information on soil is an essential in sustainable utilization of soil resources and sound land use planning. Therefore, this study was conducted with the objective of characterization and classification of soil on Askate sub-watershed, northeastern Ethiopia. Four representative soil pedons were opened along topographic position and described on each identified genetic horizons basis on the field for their morphological characteristics following the soil field description guidelines. The morphological properties were examined in the field while physical and chemical properties were analyzed in laboratory. The results of the study were revealed variation in morphological, physical, and chemical properties of the soils. Soil textural classes were sandy loam to loam sandy. The bulk density ranged from 1.04 to $1.60 \mathrm{~g} \mathrm{~cm}^{-3}$. The soil reaction rated as slightly acidic to moderate acidic (5.4 to 6.7). The OM ranged from 0.41 to $3.23 \%$ while available $P$ ranged from 0.72 to $9.36 \mathrm{mg} \mathrm{kg}^{-1}$ which was low to medium rate. The exchangeable bases ranged from low to medium rate in the study area. CEC was medium to high rate, which implies the medium nutrient reservoir of the soil. Finally, three soil types, Humic Cambisols, Haplic Luvisol, and Cambic Umbrisols were identified in the study area according to World Reference Base. Using the soils according to their potential and applications of optimum organic and inorganic fertilizers are essential to keep the sustainability of soil fertility for better crop production and productivity.
\end{abstract}

Keywords: Pedon, Soil classification, Soil characteristics, Topography.

DOI: $10.7176 / \mathrm{JBAH} / 11-3-06$

Publication date: February $28^{\text {th }} 2021$

\section{Introduction}

The productivity of agricultural soils in worldwide is currently declining and per capita food grain production decreased significantly (Shimeles et al., 2007). This decline was attributed to periodic droughts, poor management and exploitative agriculture coupled with the soil degradation (Schoonover and Crim, 2015). In Ethiopia, where agriculture is the mainstay of the national economy, its production has been highly dependent on natural resources for centuries (Kebede et al., 2017). Successful agriculture requires the sustainable use of soil resource, because soils can easily lose their quality and quantity within a short period of time for many reasons such as intensive cultivation, leaching and soil erosion (Kiflu and Beyene, 2013).

A success in soil management to maintain the soil quality depends on the understanding of how the soil responds to agricultural practices over time (Ashenafi et al., 2010). Soils provide food, fodder and fuel for meeting the basic human and animal needs. However, due to the increasing rate of population demanding food, the nutrients have been depleted and the productive capacity of soils has diminished through changes in soil characteristics (Liu et al., 2010). This demands systematic evaluation of soil resources with respect to their extent, distribution, characteristics, and use potential, which is very important for developing an effective land use system to enhance agricultural production on a sustainable basis (Pulakeshi et al., 2014).

The process of developing a soil map forces one to understand the fundamentals of soils, how the soil can formed, occur across the landscape or the globe, and how they might respond to use and management (Obasi et al., 2015). Soil mapping also aims to unravel deficiencies in our understanding of soil properties and processes both in time and space (Hartemink et al., 2012). Hence, the Ethiopian government has recently developed soil fertility map for fertilizer recommendations in various regions of the country. Major soil types identified in five districts of the Amhara region include Luvisols, Nitisols, Leptosols and Vertisols (Mekonnen, 2015). The existing few soil maps in the country are dominantly smaller scale maps of scattered areas with limited analytical data, which could not help for necessary interpretations and making site-specific land use decisions.

Different soil units such as Acrisols, Cambisols, Fluvisols, Leptosols, Luvisols, Nitisols, Vertisols and Umbrisols with various qualifiers have been identified in Ethipia (Abay and Sheleme, 2012; Daniel and Tefera, 2016; Yitbarek et al., 2016). However, the studies are limited as compared to the large land mass, and soil variability of the country. Although in-depth knowledge of soil study is a crucial, there is lack of site specific study on the soil description, characterization and classification on the study area which can use for land users and policy makers. In order to propose the possible management and give appropriate recommendation for soil resources and assess soil fertility status, soil characterization and classification are essential in the study area and it is the baseline to generate an alternative management system. Therefore, this study was initiated with the objective of characterization and classification the soils of Askate sub-watershed, northeastern Ethiopia 


\section{Materials and Methods}

\section{Description of the study area}

This study was conducted on Askate sub-watershed which is found in 027 Terad kebele, Legambo district, south Wollo zone of Amhara National Regional State, Ethiopia, which is located on $500 \mathrm{~km}$ distance from the capital city of Addis Ababa. Geographically, it is located at $39^{\circ} 8^{\prime} 0^{\prime \prime}$ to $39^{\circ} 12^{\prime} 0^{\prime \prime}$ E longitudes and $10^{\circ} 53^{\prime} 0^{\prime \prime}$ to $10^{\circ} 58^{\prime} 0 " \mathrm{~N}$ latitudes with altitude ranging from 3320 to 3650 meters above sea level (masl). The average annual rainfall is $1000 \mathrm{~mm}$ per year whereas the mean minimum and mean maximum monthly temperatures ranged from 6 to $15^{\circ} \mathrm{C}$ (LWAO, 2019). The watershed is characterized by different sloping range and topography with different land use types with highland (dega) agro-climatic zone which has the total area of 775 ha. The major geologic parent material of the area is Cenozoic volcanic rocks particularly formed from basaltic rocks (Tefera et al., 1996). Livestock and crop production is the major mixed farming system in the study area. The common crop produced in the study area is barley and somewhat wheat, lentil, and bean (LWAO, 2019).

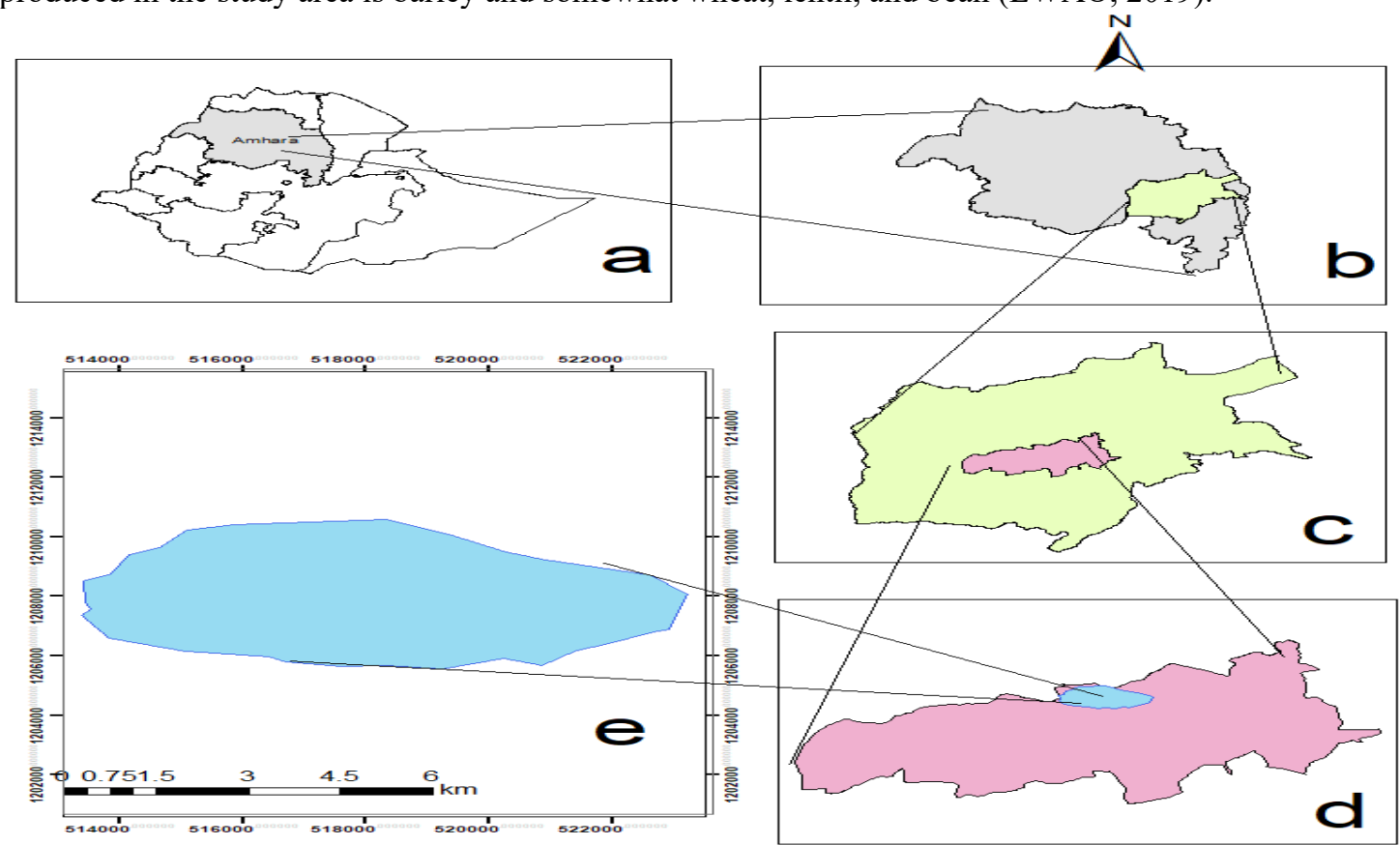

\section{Legend}

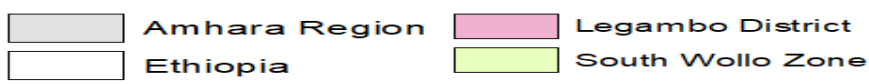

Figure 1. Location map of the study area: (a) Map of Ethiopia showing Amhara Regional State, (b) Amhara Regional State showing south Wollo zone, (c) South Wollo zone showing Legambo district,

(d) Legambo distric showing Askate watershed, and (e) Askate watershed.

\section{Field survey, profile description and soil sampling}

Prior to all, a reconnaissance field survey was carried out in order to have a general view of land use and land cover feature in the study area. Soils within watershed are carefully examined and differentiated along the landscape based on observable site and soil characteristics such as soil slope, soil depth, and texture by following the free survey method (Dent and Young, 1981).

The approach is to traverse the landscape along selected transects by auger inspection at enough points to identify the existing soils type and their boundaries. To determine the number of pedon based on heterogeneity of soil, about 150 augers samples were taken. Then after, the study area was categorized into four soil units namely: upper slope, middle slope, lower slope, and toe slope. A representative four soil pedons, $1 \mathrm{~m}$ width x $2 \mathrm{~m}$ length $\mathrm{x} 2 \mathrm{~m}$ depth were opened in each identified soil unit and described in situ following the guidelines for field soil description (FAO, 2006).

Soil color was determined using the Revised Munsell Soil Color Chart (Munsell Soil Color Chart, 1994). Soil structure was described in terms of the sequence: grade, size (class), and type (shape) of aggregates whereas horizon boundaries were described in terms of depth, distinctness, and topography. The soil consistence is identified at dry, moist and wet moisture conditions. Both disturbed and undisturbed soil samples (15 in number) were collected from each identified genetic horizon. Disturbed composite soil samples was taken from the all identified horizons from bottom to top layer by using an auger to measure the selected soil physical and chemical 
properties, where as undisturbed soil samples was taken by core sampler to measure the soil bulk density. After the composite soil sub-samples were taken and packed, it was air dried and finally ground and sieved by $2 \mathrm{~mm}$ sieve to the analysis of physical and chemical properties of soil.

\section{Laboratory analysis of soil physical and chemical properties}

Soil texture was analyzed by the Bouyoucous hydrometer method (Bouyoucous, 1962), after OM was destroyed or burned by using hydrogen peroxide $\left(\mathrm{H}_{2} \mathrm{O}_{2}\right)$, soil particles dispersed and disintegrated by sodium carbonate $\left(\mathrm{Na}_{2} \mathrm{CO}_{3}\right)$ and sodium hexametaphosphate $\left(\mathrm{NaPO}_{3}\right)$ in distilled water, and finally using amyl alcohol to destroy the soil solution foam. After the particle size distributions were determined in percent, the textural class of the soil could obtained by using USDA soil textural triangle classification system (USDA, 2008). The bulk density (BD) of the soil was measured from undisturbed soil samples collected using core sampler after drying the core samples in an oven at $105^{\circ} \mathrm{C}$ (Black, 1965). Total porosity was computed from bulk density (BD) and particle density (PD) (assuming particle density of $\left.2.65 \mathrm{gm} \mathrm{cm}^{-3}\right)$. Hence, total porosity $(\%)=(1$-Bulk density/Particle density $)^{*}(100)$

The selected chemical properties for this study include soil $\mathrm{pH}, \mathrm{EC}$, soil organic carbon (OC), total nitrogen (TN), available phosphorous, exchangeable bases ( $\mathrm{Ca}, \mathrm{Mg}, \mathrm{K}$ and $\mathrm{Na}$ ), exchangeable acidity, cation exchange capacity (CEC), and percent of base saturation. The $\mathrm{pH}$ of the soils was measured in water $\left(\mathrm{H}_{2} \mathrm{O}\right)$ solution suspension in a 1:2.5 (soil: liquid) by using $\mathrm{pH}$ meter, whereas electrical conductivity was measured by a conductivity meter (Van Reeuwijk, 1992). To determine organic carbon, the Walkley and Black (1934) method was used in which the carbon was oxidized under standard conditions with potassium dichromate $\left(\mathrm{K}_{2} \mathrm{Cr}_{2} \mathrm{O}_{7}\right)$ in sulfuric acid solution. The total nitrogen content in soils was determined using the Kjeldahl procedure by oxidizing the organic matter with sulfuric acid and converting the nitrogen into $\mathrm{NH}_{4}{ }^{+}$as ammonium sulfate as described by Jackson (1967). Determination of available phosphorous was calculated by the Olsen method using sodium bicarbonate $\left(0.5 \mathrm{M} \mathrm{NaHCO}_{3}\right)$ as extraction solution (Olsen et al., 1954).

Exchangeable bases were determined after extracting the soil samples by ammonium acetate $\left(1 \mathrm{~N} \mathrm{NH} \mathrm{NAc}_{4}\right)$ at $\mathrm{pH}$ 7.0. Exchangeable $\mathrm{Ca}$ and $\mathrm{Mg}$ in the extracts was analyzed using atomic absorption spectrophotometer (AAS), while $\mathrm{Na}$ and $\mathrm{K}$ were analyzed by flame photometer (Rowell, 1994). Exchangeable acidity was determined by Mclean (1965) method. Cation exchange capacity was estimated titrimetrically by distillation of ammonium that could be displaced by sodium from $\mathrm{NaCl}$ solution (Chapman, 1965). Percent base saturation was calculated by dividing the sum of the charge equivalents of the base-forming cations $(\mathrm{Ca}, \mathrm{Mg}, \mathrm{Na}$ and $\mathrm{K})$ by the CEC of the soil and multiplying by 100 .

\section{Statistical analysis}

After all the data collected and organized, it subjected to descriptive statistical which used to analysis the correlation amongst soil physical and chemical properties across soil horizon by the Duncan's Multiple Range Test (DMRT) using SAS software version 9.4 (SAS, 2013).

\section{Results and Discussion}

Site characteristics

The site characteristics of the pedons indicated that the study area was situated on different range of slope position. Based on the basis of slope gradient, the study area was categorized into four slope gradients: upper slope, middle slope, lower slope, and toe slope (Table 1). The opened pedons were the representative of different land use types of the study area

Table 1. Selected site characteristics of representative soil pedons of Askate sub-watershed

\begin{tabular}{ccccclll}
\hline \multirow{2}{*}{ Pedon } & \multicolumn{2}{c}{ Location (UTM) } & Altitude (masl) & Slope (\%) & Slope position & Drainage & Land use \\
\cline { 2 - 6 } & Latitude & Longitude & & & & & \\
\hline 1 & 521610 & 1207957 & 3576 & 40 & Upper & Well drained & Barley \\
\hline 2 & 522725 & 1208077 & 3357 & 20 & Middle & Well drained & Barley \\
\hline 3 & 523123 & 1207786 & 3353 & 10 & Lower & Well drained & grazing \\
\hline 4 & 523052 & 1208038 & 3345 & 5 & Toe & Moderately Well drained & Barley \\
\hline
\end{tabular}

\section{Morphological and physical properties of soil}

The soil pedons described at the upper slope, middle slope, lower slope, and toe slope positions were characterized by A-B-C, A-B-BC-C, A-B-CB-C, and Ap-A-Bt1-Bt2-horizon, respectively (Table 2). The thickness of horizons and other features of the pedons were varying among the studied pedons. The thickness of the A-horizon varied from $20 \mathrm{~cm}$ in the pedon 1 to $45 \mathrm{~cm}$ in the pedon 4 . The A- horizons in the all pedon were characterized as shallow soil depth since its less than $50 \mathrm{~cm}$. Similarly, the B-horizon in the pedon 1 was found in shallow soil depth where C- horizon was in moderately deep. Under the middle, lower, and toe slope, both A 
and B-horizons were found in the shallow soil depth where the rests were in the moderately deep soil depth.

\section{Soil color}

The soil color can be consecutively distinguished in terms of hue, chroma, and value. Across the studied pedons, the soil color was ranging between 7.5YR and 10YR, with the different units of value and chroma. The colors of all horizons in upper slope position were characteristic as dark brown color at both dry and moist level (7.5YR3/2) (Table 2). At middle and lower slope position A- horizon was dark yellowish brown color (10YR3/4), B-horizon was grewish brown color (10YR5/2) while BC and C-horizons were yellowish brown (10YR5/4) at both dry and moist soil moisture levels. In the pedon 3 the color of A-horizon is dark brown (10YR3/3) at both soil moisture levels, B and BC-horizon were black color (10YR2/1), whereas the C-horizon is gray (10YR5/1) color at dry and moist. Under the pedon 4, the horizons were varying from 7.5YR hue in Aphorizon to 10YR hue in the rests horizons. At the pedon 4, the darkness of soil color was going increased from surface to subsurface pedon which implies that there was an immigration of clay particles and attributes the dark soil colors. This might be due to the high rain fall and water impeding on the toe slope which triggers to the gradual downward movement of clay particles and other organic matters. Similarly, Alem et al. (2015) reported that soil color could be related with soil organic matter.

\section{Soil structure and consistence}

There was the variation amongst in soil structure in the studied pedons. At pedon 1, the A-horizon had weak medium angular block, whereas the rest B-horizon and C-horizons were moderate coarse sub-angular block soil structures (Table 2). The horizons of pedon 2 were characterized from weak medium granular to strong coarse sub-angular block from surface to subsurface horizons. The soil structures of pedon 3 horizons were not indicated variation amongst an identified master of horizons in which A-horizons has weak medium sub-angular block and the rests had moderate coarse granular block. The size of pedons was medium in surface horizons as compared to their subsequent subsurface soil layers. This could be attributed to continuous cultivation that decreases soil aggregates due to fragmentation by rapid wetting, exposing protected soil OM to microbial attack and the direct impact of tillage (Papiernik et al., 2007; Buol et al., 2011).

At the pedon 4- toe slope position, the soil structures were characterized by almost similar soil which was moderate grade and slightly different soil size and shape. Ap - horizon and A- horizon was characterized by moderate medium granular block soil structure, whereas Bt1 and Bt2-horizons were characterized moderate coarse sub-angular block soil structure. The grade of surface horizons were weak and their shape was changed from granular to sub angular blocky, which implies that an existence of surface organic matter. This Finding is in agreement with Fekadu et al. (2018) who reported that the presence of OM in the surface soil might be attributed to the formation of granular type of soil. The consistence of soils was slightly hard to hard at dry and slightly friable in the surface horizons of all the pedons when it was in moist, whereas wet consistency varied from sticky and plastic in the meddle slope to very sticky and very plastic in the toe slope position.

\begin{tabular}{|c|c|c|c|c|c|c|c|c|c|}
\hline \multirow[t]{2}{*}{ Depth $(\mathrm{cm})$} & \multirow[t]{2}{*}{ Horizons } & \multicolumn{2}{|c|}{ Color } & \multirow{2}{*}{$\begin{array}{c}\text { Structures } \\
\text { Grade/Size/Shape }\end{array}$} & \multicolumn{3}{|c|}{ Consistence } & \multirow{2}{*}{$\begin{array}{c}\text { Texture } \\
\text { (Feel methods) }\end{array}$} & \multirow{2}{*}{$\begin{array}{c}\text { Boundary } \\
\text { Distinct/ topography }\end{array}$} \\
\hline & & Dry & Moist & & dry & moist & Sticky, plasticity & & \\
\hline \multicolumn{10}{|c|}{ Pedon 1 (Upper slope) } \\
\hline $0-20$ & A & $7.5 \mathrm{YR} 3 / 2$ & $7.5 \mathrm{YR} 3 / 2$ & WE, ME, GR & SHA & $\overline{F R}$ & SST, SPL & SCL & $\mathrm{C}, \mathrm{S}$ \\
\hline $20-45$ & B & 7.5 YR $3 / 2$ & 10YR 3/4 & $\mathrm{MO}, \mathrm{CO}, \mathrm{SB}$ & HA & FI & SST, NPL & SL & $\mathrm{C}, \mathrm{S}$, \\
\hline $45-60$ & $\mathrm{C}$ & 7.5YR $3 / 2$ & $7.5 \mathrm{YR} 3 / 2$ & $\mathrm{MO}, \mathrm{CO}, \mathrm{SB}$ & HA & FI & SST, NPL & SL & ----- \\
\hline \multicolumn{10}{|c|}{ Pedon 2 (Middle slope) } \\
\hline $0-25$ & A & $7.5 \mathrm{YR} 3 / 2$ & 10YR 3/4 & WE, ME, GR & SHA & $\overline{\mathrm{FR}}$ & ST, PL & $\mathrm{SC}$ & $\mathrm{C}, \mathrm{S}$ \\
\hline $25-42$ & B & $10 \mathrm{YR} 5 / 2$ & 10YR 3/4 & $\mathrm{MO}, \mathrm{CO}, \mathrm{SB}$ & SHA & RI & SST,SPL & SL & $\mathrm{G}, \mathrm{B}$ \\
\hline $42-60$ & $\mathrm{BC}$ & $10 \mathrm{YR} 5 / 2$ & $10 Y R 5 / 2$ & $\mathrm{ST}, \mathrm{CO}, \mathrm{SA}$ & HA & FI & SST, NPL & SL & $\mathrm{D}, \mathrm{W}$ \\
\hline $60-70+$ & $\mathrm{C}$ & $10 \mathrm{YR} 5 / 2$ & $10 \mathrm{YR} 5 / 2$ & $\mathrm{ST}, \mathrm{CO}, \mathrm{SA}$ & HA & FI & SST, NPL & SL & ----- \\
\hline \multicolumn{10}{|c|}{ Pedon 3 (Lower slope) } \\
\hline $0-25$ & A & 7.5 YR $5 / 2$ & $10 \mathrm{YR} 3 / 3$ & ST, ME, GR & VHA & VFR & SST, SPL & $\mathrm{S}$ & $\mathrm{C}, \mathrm{S}$ \\
\hline $25-40$ & B & $7.5 \mathrm{YR} 3 / 2$ & 10YR $2 / 1$ & MO, ME, GR & HA & FR & SST, SPL & SL & $\mathrm{C}, \mathrm{W}$ \\
\hline $40-60$ & $\mathrm{CB}$ & 10YR 2/1 & 10YR 2/1 & $\mathrm{MO}, \mathrm{CO}, \mathrm{SB}$ & SHA & FI & ST, PL & LS & $\mathrm{A}, \mathrm{W}$ \\
\hline $60-80+$ & $\mathrm{C}$ & 10YR 5/1 & 10YR 2/1 & $\mathrm{MO}, \mathrm{CO}, \mathrm{SB}$ & HA & FI & VST,VPL & LS & ------ \\
\hline \multicolumn{10}{|c|}{ Pedon 4 (Toe slope) } \\
\hline $0-20$ & Ap & 7.5 YR $3 / 2$ & $7.5 \mathrm{YR} 4 / 1$ & WE, ME, GR & SHA & FR & ST, PL & SL & $\mathrm{D}, \mathrm{S}$ \\
\hline $20-45$ & A & 10YR 2/1 & $10 \mathrm{YR} 3 / 2$ & $\mathrm{MO}, \mathrm{ME}, \mathrm{GR}$ & SHA & FR & SST, PL & SCL & $\mathrm{C}, \mathrm{S}$ \\
\hline $45-73$ & Bt1 & 10YR $3 / 2$ & 10YR 4/1 & $\mathrm{MS}, \mathrm{CO}, \mathrm{SB}$ & HA & FI & VST,VPL & SL & $\mathrm{G}, \mathrm{W}$ \\
\hline 73-97+ & Bt2 & 10YR 3/1 & 10YR 3/1 & $\mathrm{ST}, \mathrm{CO}, \mathrm{SB}$ & VHA & VFI & VST, PL & SL & ----- \\
\hline
\end{tabular}

Structure: $\mathrm{WE}=$ Weak, $\mathrm{MO}=$ Moderate, $\mathrm{MS}=$ Moderately strong, $\mathrm{ST}=$ Strong, $\mathrm{ME}=$ medium, $\mathrm{CO}=$ Coarse, $\mathrm{SB}=$ Sub-angular blocky, $\mathrm{GR}=$ Granular, $\mathrm{SA}=$ Sub angular and angular blocky. Consistence: $\mathrm{SHA}=$ Slightly hard, $\mathrm{HA}=$ Hard, VHA=Very hard, FR= Friable; FI=Firm; VFI=Very firm, SST= Slightly sticky, ST=Sticky, $\mathrm{VST}=$ Very sticky, $\mathrm{NPL}=$ None plastic, $\mathrm{PL}=\mathrm{Plastic} ; \mathrm{SPL}=$ Slightly plastic, $\mathrm{VPL}=$ Very plastic. Texture: $\mathrm{LS}=$ Loamy sandy, $\mathrm{S}=\mathrm{Sandy}, \mathrm{SL}=$ Sandy loam, $\mathrm{SC}=$ Sandy clay, $\mathrm{SCL}=$ Sandy clay loam. Horizon boundary: $\mathrm{A}=$ Abrupt, $\mathrm{B}=$ Broken, $\mathrm{C}=$ Clear, $\mathrm{D}=$ Diffuse, $\mathrm{G}=$ Gradual, $\mathrm{S}=$ Smooth, $\mathrm{W}=$ wavy. 


\section{Horizon boundary}

The horizons of all pedons had varied distinctness and topography across identified pedons. All the horizons of pedon 1 had clear distinctness and smooth topography, where pedon 2 and 3 had various distinctness and gradual topography. Pedon 4 was also characterized by different horizons distinct while it has smooth and wavy horizons topography (Table 2). The existence of these variations in boundary characteristics between surface and subsurface soil layer could reflect the presence of distinct morphological features with pedon depth, which in turns indicate the early stages of soil development in the study areas (Ukut et al, 2014).

Table 3: Selected physical characteristics of soil pedons of Askate sub-watershed

\begin{tabular}{|c|c|c|c|c|c|c|c|}
\hline \multirow[t]{2}{*}{ Depth $(\mathrm{cm})$} & \multirow[t]{2}{*}{ Horizon } & \multicolumn{3}{|c|}{ Soil texture $(\%)$} & \multirow[t]{2}{*}{ Textural class } & \multirow[t]{2}{*}{$\mathrm{BD}\left(\mathrm{g} \mathrm{cm}^{-3}\right)$} & \multirow[t]{2}{*}{ ТP $(\%)$} \\
\hline & & Sand & Silt & Clay & & & \\
\hline \multicolumn{8}{|c|}{ Pedon 1 (Upper slope) } \\
\hline $0-20$ & A & 70 & 23 & 7 & Loam sandy & 1.08 & 59.24 \\
\hline $20-45$ & B & 64 & 29 & 7 & Sandy loam & 1.07 & 59.62 \\
\hline $45-60$ & $\mathrm{C}$ & 60 & 29 & 11 & Sandy loam & 1.40 & 47.17 \\
\hline \multicolumn{8}{|c|}{ Pedon 2 (Middle slope) } \\
\hline $0-25$ & A & 62 & 31 & 7 & Sandy loam & 1.04 & 60.75 \\
\hline $25-42$ & $\mathrm{~B}$ & 58 & 23 & 19 & Sandy loam & 1.07 & 59.62 \\
\hline $42-60$ & $\mathrm{BC}$ & 46 & 29 & 25 & Loam & 1.41 & 53.23 \\
\hline $60-70+$ & $\mathrm{C}$ & 48 & 17 & 35 & Sandy clay loam & 1.60 & 40.00 \\
\hline \multicolumn{8}{|c|}{ Pedon 3 (Lower slope) } \\
\hline $0-25$ & A & 62 & 33 & 5 & Sandy loam & 1.40 & 47.17 \\
\hline $25-40$ & $\mathrm{~B}$ & 70 & 24 & 6 & Loam sand & 1.42 & 46.42 \\
\hline $40-60$ & $\mathrm{CB}$ & 70 & 25 & 5 & Loam sand & 1.43 & 46.04 \\
\hline $60-80+$ & $\mathrm{C}$ & 70 & 23 & 7 & Loam sand & 1.44 & 45.66 \\
\hline \multicolumn{8}{|c|}{ Pedon 4 (Toe slope) } \\
\hline $0-20$ & Ap & 56 & 43 & 1 & Sandy loam & 1.34 & 49.43 \\
\hline $20-45$ & A & 54 & 31 & 15 & Sandy loam & 1.42 & 46.42 \\
\hline $45-73$ & Bt1 & 52 & 27 & 21 & Sandy clay loam & 1.46 & 44.91 \\
\hline $73-97+$ & $\mathrm{Bt} 2$ & 58 & 23 & 19 & Sandy loam & 1.54 & 41.89 \\
\hline
\end{tabular}

Notes: $\mathrm{BD}=$ Bulk density, $\mathrm{TP}=$ Total porosity

\section{Soil texture}

The trend of soil textures were characterized by different values within the identified horizons despite it had differed from pedons to pedons (Table 3). Sand soil particle was relatively going decreased from surface to subsurface soil pedons in all horizons while it did not show more variation in pedon 3 . Silt soil particles were shows irregular change in the pedons. Clay particle was almost irregularly going increased with the soil depth in all soil pedons except in pedon 3 , in which did not show more variation. This might be due the downward migration of clay particle. In general, the soil texture across the opened pedons were did not show the regular change along the topographic position and soil depths, which might be due to high rainfall and subsequent sever soil erosion of study area.

This findings is in parallel with the result of Alem et al. (2015) who reported that lack of definite trend in soil texture along the topographic position might be due to the dominance of erosion and accumulation in influencing the pedogenic processes, whereas irregular trend with depth, might be due to variation in weathering of parent material (Daniel and Tefera, 2016).

\section{Bulk density and total porosity}

The bulk densities of the studied area were varied from 1.04 to $1.40 \mathrm{~g} \mathrm{~cm}^{-3}$ on the surface, and from 1.07 to 1.60 $\mathrm{g} \mathrm{cm}^{-3}$ in the subsurface horizons of the soil pedon (Table 3 ). The relatively lower bulk density values obtained at the surface soil horizons, which could be related to the structural aggregation of the soils as a result of relatively high OM content. The bulk density along identified soil horizons were increased with depth which might be due to weight of the overlying soil and the relatively low amount of OM in the subsurface soil layers. Similarly, Chaudhari et al. (2013) reported that an increment of bulk density with pedon depth could be due to the changes in OM content, porosity, and soil compaction. The critical value of bulk density for plant growth at which root penetration is likely to be severely restricted is 1.10 to $1.60 \mathrm{~g} \mathrm{~cm}^{-3}$ for most mineral soils (Hazelton and Murphy, 2007). Following this critical value, the bulk density values of the surface horizons in the crop lands were in the favorable range. In contrast, the total porosity decreased along the horizons of all soil pedons in the study site. The total porosity of the studied watershed ranged from $41.89 \%$ in pedon 4 to $60.75 \%$ in pedon 2 of the surface and subsurface soil horizons, respectively (Table 3 ). 
According to Gupta (2004), the ideal porosity value for healthy root growth is greater than $40 \%$ for sandy soil particles and greater than $50 \%$ for that of clay particles. Hence, porosity values of the recognized pedons in the surface layers are in the acceptable range for crop production and productivities. The bulk density of the soil was insignificantly and negatively correlated with clay particles values at $r=-0.38$, while it was insignificantly and positively correlated with sand and silt particles values $r=0.28$ and $r=0.20$, respectively. But it was significantly and negatively $\left(\mathrm{r}=-0.97^{* *}\right)$ correlated with the total porosity (Table 7$)$. This might be due to the reciprocal relationship between soil bulk density and total porosity, which shows the degree of soil compaction and the situation of soil aeration.

\section{Soil chemical properties}

Soil reaction $(\mathrm{pH})$ and electrical conductivities $(\mathrm{EC})$

The soil $\mathrm{pH}\left(\mathrm{H}_{2} \mathrm{O}\right)$ values of the pedon 2 and 4 were relatively going increased within the soil depth whereas it did not shows regular variation in the pedon 1 and 3.The highest (6.7) values of soil reaction was recorded at the pedon 2 in BC- and C-horizons while the lowest (5.4) values were recorded at the pedons 1 and 4 in B and Aphorizons, respectively (Table 4). The downward increment of soil $\mathrm{pH}$ might be due the depletion of basic cation and removal of surface soil organic matter as a result of heavy rain fall of study area that trigger an acceleration of soil erosion. These findings are in line with the results of Yimer and Abdulkadir (2011), and Kiflu et al. (2016), in their results they revealed that the depletion of basic cation by rain fall and removal of crops residues could be causes for the surface soil acidic compared to subsurface soil layer. According to Hazelton and Murphy (2007), the values of soil reaction under the studied pedons were rated as slightly to moderately acidic.

The highest $\left(0.16 \mathrm{dS} \mathrm{m}^{-3}\right)$ value of EC was measured in the sub-surface soil layers of the pedon 1, whereas the lowest $\left(0.02 \mathrm{dS} \mathrm{m}^{-3}\right)$ value was in the surface soil layer of pedon 2 (Table 4$)$. The values of EC were generally almost showed systematic pattern with the soil depth and topographic position in all pedons, except a slightly indicated irregular variation at pedon1. According to Landon (1991) salinity classification, a soil is required to possess EC values greater than $4 \mathrm{dS} \mathrm{m}^{-3}$ in order to qualify for saline and saline-sodic soil. Generally, the EC values measured throughout the depths of the soils in the study area indicated the concentration of soluble salts for below the levels atwhich growth and productivity of most agricultural crops are limited, in which the salinity problems is not appeared in the watershed.

\section{Soil organic matter}

The values of soil organic matter (OM) were relatively higher in the surface horizons and become low in the subsoil horizons of the pedons. Considering the surface soils, the highest (4.68\%) value of OM content was measured in the A-horizon of pedon 4) (Table 4). The trend of soil OM in the watershed was regularly going decrease with the soil depth though there was no systemic variation along topographic position of the studied watershed.

Compared to the rest soil pedons, pedon 4 had high soil OM which could be due to the processes of weathering and transportation of surface materials from upper slope and deposited at toe slope position. Many research reported in Ethiopia supported this finding (Yimer and Abdulkadir, 2011; Daniel and Tefera, 2016; Kebede et al., 2017). The soil OM values were rated as low in all cases except in the A-horizons of pedon 2 and 4, which was in the range of medium rate (Tekalign, 1991). Soil OM was insignificantly and positively correlated with the soil total porosity, clay and CEC at $r=0.31$, at $r=0.24$, and at $r=0.43$, respectively, while it was significantly and positively correlated with the soil total $\mathrm{N}$ and silt particles at $\mathrm{r}=0.95^{* *}$ and at $\mathrm{r}=0.69^{* *}$, respectively (Table 7). This positive relationship between soil OM, clay particle and CEC confirm that the more soil OM, the more potential of the nutrient reservoir of the soil on soil colloidal phase.

\section{Total nitrogen and carbon to nitrogen ratio (C:N)}

The total $\mathrm{N}$ content of soils was directly associated with soil OM content along the soil depth and topographic position. The highest $(0.34 \%)$ value of total $\mathrm{N}$ was recorded in the surface horizon of pedon 4 , where the lowest $(0.03 \%)$ OM value was obtained in subsurface soil layer of pedon 3 (Table 4). According to Tekalign (1991), the total $\mathrm{N}$ contents of the surface layers of pedons 1,2 , and 3 were rated as medium $(0.12$ to $0.25 \%)$ while it was rates as high $(>0.25 \%)$ in the surface soil layer of pedon 4 . This result is in agreement with the findings of Zeleke and Kibebew (2009), Assen and Yilma (2010); and Fekadu et al. (2018) who reported that the direct relation of total $\mathrm{N}$ and soil $\mathrm{OM}$ as well as high surface OM compared to subsurface soil layer which related with surface biomass. The carbon to nitrogen $(\mathrm{C}: \mathrm{N})$ ratio of soils ranged from narrow to the medium range $(8: 1$ to 12:1) which could not adversely affect the mineralization processes (Havlin et al., 1999).

\section{Available phosphorous}

Available P contents did not show any systematic variation across the topographic positions and soil depth. Available $\mathrm{P}$ contents ranged from 0.72 to $9.36 \mathrm{mg} \mathrm{kg}^{-1}$ (Table 4). According to the rating of available $\mathrm{P}$ cited by 
Olsen et al. (1954), the available $\mathrm{P}$ content of the soils was in the range of low $\left(<5 \mathrm{mg} \mathrm{kg}{ }^{-1}\right)$ to medium rate (5 to $10 \mathrm{mg} \mathrm{kg}^{-1}$ ). Generally, the available phosphorous in the studied watershed indicated that the deficiencies of available $\mathrm{P}$. This might be due to the low of inherent $\mathrm{P}$ occurrence and low soil weathering which in turns release low organic phosphorous in the study area. Similarly, the phosphorus deficiency in Ethiopian soils is well documented by different researchers (Melese et al., 2015; Tufa et al., 2019), which might be as a result of low P inheritance.

Table 4: Selected chemical properties of soil pedons of Askate sub-watershed

\begin{tabular}{|c|c|c|c|c|c|c|c|}
\hline Depth $(\mathrm{cm})$ & Horizons & $\mathrm{pH}\left(\mathrm{H}_{2} \mathrm{O}\right)$ & $\mathrm{EC}\left(\mathrm{d} \mathrm{Sm}^{-3}\right)$ & $\mathrm{OM}(\%)$ & $\mathrm{TN}(\%)$ & $\mathrm{C}: \mathrm{N}$ & Av. P $\left(\mathrm{mg} \mathrm{kg}^{-1}\right)$ \\
\hline \multicolumn{8}{|c|}{ Pedon 1 (Upper slope) } \\
\hline $0-20$ & A & 5.8 & 0.10 & 2.62 & 0.19 & 8.0 & 0.76 \\
\hline $20-45$ & B & 5.4 & 0.16 & 1.54 & 0.09 & 9.9 & 0.76 \\
\hline $45-60$ & $\mathrm{C}$ & 6.1 & 0.10 & 1.10 & 0.08 & 7.9 & 5.36 \\
\hline \multicolumn{8}{|c|}{ Pedon 2 (Middle slope) } \\
\hline $0-25$ & A & 6.1 & 0.02 & 3.24 & 0.36 & 7.9 & 2.64 \\
\hline $25-42$ & B & 6.5 & 0.09 & 1.66 & 0.12 & 8.2 & 3.62 \\
\hline $42-60$ & $\mathrm{BC}$ & 6.7 & 0.09 & 1.24 & 0.09 & 8.0 & 6.96 \\
\hline $60-70+$ & $\mathrm{C}$ & 6.7 & 0.09 & 0.96 & 0.05 & 8.0 & 9.36 \\
\hline \multicolumn{8}{|c|}{ Pedon 3 (Lower slope ) } \\
\hline $0-25$ & A & 5.9 & 0.03 & 1.38 & 0.10 & 8.0 & 3.94 \\
\hline $25-40$ & $\mathrm{~B}$ & 6.1 & 0.03 & 1.10 & 0.08 & 8.5 & 1.68 \\
\hline $40-60$ & $\mathrm{CB}$ & 5.9 & 0.04 & 0.69 & 0.05 & 8.5 & 1.24 \\
\hline $60-80+$ & $\mathrm{C}$ & 6.2 & 0.05 & 0.41 & 0.03 & 8.2 & 0.72 \\
\hline \multicolumn{8}{|c|}{ Pedon 4 (Toe slope) } \\
\hline $0-20$ & Ap & 5.4 & 0.06 & 4.68 & 0.34 & 7.9 & 1.72 \\
\hline $20-45$ & A & 5.6 & 0.07 & 2.34 & 0.17 & 8.0 & 4.12 \\
\hline $45-73$ & Bt1 & 6.3 & 0.09 & 2.07 & 0.15 & 8.2 & 1.62 \\
\hline $73-97+$ & Bt2 & 6.6 & 0.08 & 1.93 & 0.14 & 8.0 & 2.20 \\
\hline
\end{tabular}

Notes: $\mathrm{EC}=$ Electrical conductivity, $\mathrm{TN}=$ Total nitrogen, Av. $\mathrm{P}=$ Available phosphorous

\section{Exchangeable bases}

The trend of exchangeable $\mathrm{Ca}$ did not show any systematical pattern in both across the topographic position and soil depth. The highest $\left(0.76 \mathrm{cmol}_{\mathrm{c}} \mathrm{kg}^{-1}\right)$ exchangeable $\mathrm{Ca}$ value was recorded in the subsurface soil layer of pedon 2, whereas the lowest $\left(0.25 \mathrm{cmol}_{\mathrm{c}} \mathrm{kg}^{-1}\right)$ was recorded in the subsurface layer of pedon 1 (Table 5). Relatively, the accumulation of Ca going increased with soil depth which might be due to its leaching by high rainfall of the study area. Similarly, Nahusenay et al. (2014) reported that accumulation of exchangeable Ca increase from top to bottom soil horizons with depth which could be due to its leaching from the overlying horizons. As per the rating of FAO (2006) the concentration of exchangeable Ca observed in all surface and subsurface horizons are categorized as low level. 
Table 5: Selected chemical properties of soil pedon of Askate sub-watershed

\begin{tabular}{|c|c|c|c|c|c|c|c|c|}
\hline Depth $(\mathrm{cm})$ & Horizons & $\mathrm{Ca}^{2+}$ & $\mathrm{Mg}^{2+}$ & $\mathrm{K}^{+}$ & $\mathrm{Na}^{+}$ & $\mathrm{CEC}$ & EA & PBS (\%) \\
\hline \multicolumn{9}{|c|}{$\mathrm{cmol}_{\mathrm{c}} \mathrm{kg}^{-1}$} \\
\hline \multicolumn{9}{|c|}{ Pedon 1 (Upper slope) } \\
\hline $0-20$ & A & 0.51 & 2.57 & 5.48 & 0.15 & 38.9 & 0.05 & 22.30 \\
\hline $20-45$ & B & 0.25 & 1.23 & 5.26 & 0.17 & 38.7 & 0.06 & 17.90 \\
\hline $45-60$ & $\mathrm{C}$ & 0.33 & 2.02 & 6.49 & 0.33 & 37.8 & 0.01 & 24.30 \\
\hline \multicolumn{9}{|c|}{ Pedon 2 (Middle slope) } \\
\hline $0-25$ & A & 0.74 & 2.48 & 0.28 & 0.89 & 43.4 & 0.04 & 10.11 \\
\hline $25-42$ & B & 0.64 & 2.75 & 0.49 & 0.39 & 50.9 & 0.06 & 8.40 \\
\hline $42-60$ & $\mathrm{BC}$ & 0.76 & 2.61 & 0.55 & 0.43 & 47.9 & 0.14 & 9.10 \\
\hline $60-70+$ & $\mathrm{C}$ & 0.52 & 2.12 & 0.61 & 0.39 & 52.9 & 0.05 & 6.90 \\
\hline \multicolumn{9}{|c|}{ Pedon 3 (Lower slope) } \\
\hline $0-25$ & A & 0.42 & 1.34 & 1.28 & 0.14 & 43.0 & 0.02 & 7.40 \\
\hline $25-40$ & B & 0.29 & 1.19 & 0.38 & 0.19 & 52.6 & 0.01 & 4.11 \\
\hline $40-60$ & $\mathrm{CB}$ & 0.73 & 2.85 & 0.37 & 0.2 & 40.2 & 0.01 & 10.32 \\
\hline $60-80+$ & $\mathrm{C}$ & 0.57 & 2.7 & 0.05 & 0.41 & 40.2 & 0.03 & 9.40 \\
\hline \multicolumn{9}{|c|}{ Pedon 4 (Toe slope) } \\
\hline $0-20$ & Ap & 0.43 & 2.05 & 0.32 & 0.19 & 47.6 & 0.01 & 6.34 \\
\hline $20-45$ & A & 0.40 & 3.05 & 0.32 & 0.2 & 45.9 & 0.04 & 8.63 \\
\hline $45-73$ & Bt1 & 0.49 & 2.6 & 0.05 & 0.48 & 54.2 & 0.02 & 6.70 \\
\hline $73-97+$ & $\mathrm{Bt} 2$ & 0.46 & 2.17 & 0.46 & 0.25 & 52.1 & 0.07 & 6.40 \\
\hline
\end{tabular}

Notes: $\mathrm{EA}=$ Exchangeable acidity, $\mathrm{CEC}=$ Cation exchangeable capacity, $\mathrm{PBS}=$ Percent base saturation

The exchangeable $\mathrm{Mg}$ was unsystematically shoes various range in the studied horizons. The highest (3.05) and the lowest $\left(1.19 \mathrm{cmol}_{\mathrm{c}} \mathrm{kg}^{-1)}\right.$ values of exchangeable $\mathrm{Mg}$ contents were found under subsoil of pedon 4 and pedon 3, respectively (Table 5). The values of exchangeable $\mathrm{Mg}$ were unsystematically gonging increased along topographic position and downward soil depth, which could be attributed to the high rain fall and subsequent leaching. According to FAO (2006), the concentrations of exchangeable Mg in all soil pedon were categorized as medium rates. The level of magnesium in the soils was high compared to that of exchangeable Ca. This implies that the presence of sufficient magnesium bearing rock and parent material through weathering and decomposition from which the soil was formed in the soils of the study area.

The highest $\left(6.49 \mathrm{cmol}_{\mathrm{c}} \mathrm{kg}^{-1}\right)$ value of exchangeable $\mathrm{K}$ was recorded at subsoil in pedon 1 at $\mathrm{C}$ - horizon while the lowest $\left(0.05 \mathrm{cmol}_{\mathrm{c}} \mathrm{kg}^{-1}\right)$ value was recorded at pedon 3 and 4 in $\mathrm{C}$ and Bt1-horizons, respectively. The exchangeable $\mathrm{K}$ in the study area decreased systematically downward topographic position and increase unsystematically with the soil depth of all pedons. The declined of exchangeable $\mathrm{K}$ downward topographic position might be due to the low susceptible to leaching compared to exchangeable $\mathrm{Ca}$ and $\mathrm{Mg}$. According to rating set by FAO (2006) the exchangeable $\mathrm{K}$ observed in all horizons of identified pedons were rated as low except in pedon 1 , which it was rated ad medium very high levels. This result was in parallel with the findings of Tena and Beyene (2011) who reported $\mathrm{K}^{+}$deficiency in Alfisols.

The highest $\left(0.89 \mathrm{cmol}_{\mathrm{c}} \mathrm{kg}^{-1}\right)$ and the lowest $\left(0.14 \mathrm{cmol}_{\mathrm{c}} \mathrm{kg}^{-1}\right)$ values of exchangeable $\mathrm{Na}$ were recorded at surface soil layer of pedon 2 and 3 in A- horizon, respectively (Table 5). Exchangeable Na in the study area inconsistently increases down topographic position and regularly increases with soil depth in all identified soil pedons. This could be attributed to downward movement of exchangeable $\mathrm{Na}$ by erosion and leaching to subsurface by rainfall. According to FAO (2006) the exchangeable Na study area rated as low in all pedon, which implies that the study area was free from sodicity problems.

In general principal, the cations occupying the exchangeable site were in the order of $\mathrm{Ca}^{2+}>\mathrm{Mg}^{2+}>\mathrm{K}^{+}>\mathrm{Na}^{+}$. But this finding was contradict this principles in which the exchangeable $\mathrm{Mg}$ was become the dominated cation compared to the rests. The exchangeable base of soils in the study area was mostly saturated with $\mathrm{Mg}^{2+}$ which was followed by $\mathrm{Ca}^{2+}, \mathrm{K}^{+}$and $\mathrm{Na}^{+}$. This might be resulted from the weathering of $\mathrm{Mg}$-rich parent material of the study area.

\section{Cation exchangeable capacity}

The highest $\left(54.2 \mathrm{cmol}_{\mathrm{c}} \mathrm{kg}^{-1}\right)$ and the lowest $\left(37.8 \mathrm{cmol}_{\mathrm{c}} \mathrm{kg}^{-1}\right)$ values of cation exchange capacity of the soils were found in sub-surface layers of pedon 4 and 1, respectively (Table 5). Relatively, the values of cation exchange capacity of the soil was high in subsurface layer than the surface soil layer, which might be due to the presence of exchangeable bases those leached from top layers and accumulated at the bottom of soil layer as a result of heavy rain fall of the study area.

Similarly, Papiernik, et al. (2007) and Nahusenay et al. (2014) reported that accumulation of exchangeable 
bases with soil depth could be due to leaching from the overlying horizons. According to Hazelton and Murphy (2007), the cation exchange capacities of all soil pedons were relatively in the range of medium to high rate. The CEC of the soil was insignificantly and positively correlated with the total porosity $(\mathrm{r}=0.38)$, total $\mathrm{N}(\mathrm{r}=0.32)$, and available $\mathrm{P}(\mathrm{r}=0.30)$ while it was significantly and positively correlated with the clay particle $(\mathrm{r}=0.59 * *)$, $\mathrm{pH}\left(\mathrm{r}=0.54^{*}\right)$ and PBS $\left(0.76^{* *}\right)$. But it was significantly and negatively correlated with the sand particle at $\mathrm{r}=$ $0.53 *$ (Table 7).

\section{Exchangeable acidity and percent base saturation}

Across the soil horizons of the identified pedons, the highest $\left(0.14 \mathrm{cmol}_{\mathrm{c}} \mathrm{kg}^{-1}\right)$ value of exchangeable acidity was recorded in pedon 2 followed by $0.0 .07 \mathrm{cmol}_{\mathrm{c}} \mathrm{kg}^{-1}$ in the pedon 4 whereas the lowest $\left(0.01 \mathrm{cmol}_{\mathrm{c}} \mathrm{kg}^{-1}\right)$ value of exchangeable acidity was recorded in pedon 3 followed by $\left(0.02 \mathrm{cmol}_{\mathrm{c}} \mathrm{kg}^{-1}\right)$ at pedon 4 (Table 5). Relatively, the higher exchangeable acidity at the pedon 2 in the BC-horizon, under cultivated land could be ascribed to the intensive cropping which causes removal of basic cations via crop harvest since the crop might be release the $\mathrm{H}^{+}$ during uptake of others basic cation in order to keep the natural balance of colloidal surface. Different researches were confirmed these factors those increased exchangeable acidity in the soil mainly enhancing depletion of basic cations especially in surface horizons (Alem et al., 2015; Yitbarek et al., 2016; Fekadu et al., 2018). The percent of base saturation in the study area ranged from 4.11 to $24.30 \%$ (Table 5). According to Hazelton and Murphy (2007), PBS was in the range of very low rate. This implies the high leaching of exchangeable bases in the study area which might be due to heavy rain fall of the study area.

\section{Soil classification}

The soil classification was done according to the procedure of World Reference Base (WRB) and soil taxonomy (FAO, 2014). The morphological properties in the field description and the physical and chemical analysis results of the soil samples collected from every identified horizon were also used for the soil classifications in the study area.

Soil classification according to WRB: Pedon 1 was opened in cultivated land which was limited in soil depth, loam sand in soil texture and granular in structure with well drainage system. The pedon had greater than $4 \%$ clay, greater than 2 hue units, and greater than 1 chroma units of soil color. These attributes of the pedon qualify the diagnostic criteria for cambic subsurface horizon. Additionally, the pedon had a percent base saturation of less than $50 \%$ (by $1 \mathrm{M} \mathrm{NH}_{4} \mathrm{OAc}$ ) between 20 and $50 \mathrm{~cm}$ of the soil surface, which qualifies for hyperdystric principal qualifier. Furthermore, the presence of greater than $1 \%$ organic carbon to a depth of $50 \mathrm{~cm}$ from the surface soil indicates the soil to have Humic supplementary qualifier. Therefore, based on these criteria, the soil is classified as Hyperdystric Cambisols (Humic) (FAO, 2014).

Pedon 2 and 3 had higher clay content in the subsoil than in the topsoil i.e. higher clay than an overlying horizon which fulfilled argic subsurface horizon properties. The movement and buildup of clay formed argic subsoil horizon which has sandy loam textural class. Soils with high activity clays throughout the argic horizon and a low percent base saturation (by $1 \mathrm{M} \mathrm{NH}_{4} \mathrm{OAc}$ ) in the 50 to $100 \mathrm{~cm}$ soil depth satisfy the definition of Luvisols as a reference soil group. These characteristics entirely defined the soil without the requirement of other principal qualifier and thus Haplic was prefixed. However, the percent base saturation of less than $50 \%$ between 20 to $50 \mathrm{~cm}$ from the surface makes the use of epidystric supplementary qualifier to classify the soil of pedon 2 and 3 as Haplic Luvisols (Epidystric).

Pedon 4 had weak medium granular structure on the surface, Munsell colour a value of less than 5 and less than or equal to 3 a chroma units at both moist. It had also high OC contents with dark brown color and a percent base saturation (by $1 \mathrm{M} \mathrm{NH}_{4} \mathrm{OAc}$ ) less than $50 \%$ on a weighted average, throughout the entire thickness of the horizon with acid in reaction thus qualifying as umbric (FAO, 2014). The horizon has significant accumulation of $\mathrm{OC}$ in the mineral surface soil and a low percent base saturation within the soil depth of $100 \mathrm{~cm}$. This pedon was therefore, recognized to meet Umbrisols at reference soil group. The subsurface horizon shows some evidence of pedogenetic alteration, and higher clay content than the bottom layer. The pedogenetic alteration is identified from the overlying mineral horizon, which is richer in $\mathrm{OM}$ and therefore have a darker colour, indicating cambic as a principal qualifier. Due to the accumulation of colluvic materials which has been transported as a result of erosion wash or soil creep in the slope positions, the supplementary qualifier colluvic is added as a suffix, and hence the soil is classified under Cambic Umbrisols (Colluvic).

Soil classification according to Soil Taxonomy: All the soil pedons had thickness of 20 to $45 \mathrm{~cm}$ in the surface horizons, having moist color of $7.5 \mathrm{YR} 3 / 2$ to $10 \mathrm{YR} 5 / 2$ darker and mostly weak to moderately strong structure with low percent base saturation. Pedon 1 had greater than $0.6 \%$ organic carbon with percent base saturation of less than 50 (by $1 \mathrm{M} \mathrm{NH}_{4} \mathrm{OAc}$ ). Additionally, it had higher clay content than the overlying horizons, qualifying cambic subsurface diagnostic horizon, hence, it was classified as Inceptisols order of soil taxonomy. It was also classified under Ustepts due to its ustic moisture regime and the pedon was further classified as Haplustepts and Typic Haplustepts (Table 6). Pedons 2 and 3 had an argic subsurface horizon with Luvisol soil unit so that it 
classified under Alfisols order of soil taxonomy. The pedons were further grouped under Ustalfs at suborder level due to their ustic soil moisture regime and Haplustalfs and Typic Haplustalfs, at great group and subgroup levels, respectively. Considering the ustic soil moisture regime, pedon 4 with umbric horizon lithic contact within $100 \mathrm{~cm}$ pedon depth was classified as Entisols. The pedon was further classified as Ustorthents suborders due to its ustic moisture regime and horizon thickness more than $18 \mathrm{~cm}$ within $100 \mathrm{~cm}$ soil depth and grouped under Lithic Ustorthents (FAO. 2014).

Table 6: Diagnostic horizons, properties, qualifiers and soil types of the study area according to (FAO, 2014) soil classification system

\begin{tabular}{lllll}
\hline \multirow{2}{*}{ Pedon } & \multicolumn{2}{c}{ Diagnostic horizon } & Soil unit (FAO, 2014) & Soil type \\
& Surface & Subsurface & & \\
\hline 1 & ---- & Cambic & Hyperdystric Cambisols(Humic) & Typic Haplustepts \\
2 & Mollic & Argic & Haplic Luvisol(Epidystric) & Typic Haplustalfs \\
3 & Mollic & Argic & Haplic Luvisol(Epidystric) & Typic Haplustalfs \\
4 & Mollic & Umbric & Cambic Umbrisols (Colluvic) & Lithic Ustorthents \\
\hline
\end{tabular}

\section{Conclusion}

Adequate information on soil characteristics and classification is a vital for maintaining soil productivity and realization of land use planning. Therefore, soil characterization, and classification was conducted at Askate subwatershed in Legambo district, south Wollo zone, Ethiopia. Four representative soil pedons were opened along topographic position and described on each identified genetic horizons basis on the field for their morphological characteristics. The morphological properties were examined in the field while physical and chemical properties were analyzed in laboratory. The results of the study were revealed variation in morphological, physical, and chemical properties of the soils. The sand content in the all horizons of all pedons was higher as compared to the others soil particles. The $\mathrm{pH}$ of soils ranged from slightly to moderately acidic. The exchangeable basic cations were low at the surface and subsurface which may influence crop growth adversely. The soils had low to medium organic matter and available P, while medium rate of CEC. According to World Reference Base, the soils of study area were classified as Humic Cambisols (humic), Haplic Luvisol (epidystric), and Cambic Umbrisol (colluvic) with their soil taxonomy equivalent to Typic Haplustepts, Typic Haplustalfs, and Lithic Ustorthents, respectively. Therefore, using the soils according to their potential utility and land suitability as well as applications of optimum organic and inorganic fertilizers are essential to keep the sustainability of soil fertility for better crop production and productivity.

Table 7: Pearson's correlation matrix for selected soil physical and chemical parameters

\begin{tabular}{|c|c|c|c|c|c|c|c|c|c|c|c|c|c|c|c|c|c|c|}
\hline & Sand & Silt & Clay & $\mathrm{BD}$ & TP & $\mathrm{pH}$ & EC & $\mathrm{OM}$ & TN & $\mathrm{C}: \mathrm{N}$ & $A v, P$ & $\mathrm{Na}^{+}$ & $\mathrm{K}^{+}$ & $\mathrm{Mg}^{2+}$ & $\mathrm{Ca}^{2+}$ & CEC & EA & PBS \\
\hline Sand & 1.00 & & & & & & & & & & & & & & & & & \\
\hline Silt & -0.19 & 1.00 & & & & & & & & & & & & & & & & \\
\hline Clay & $-0.77^{* *}$ & -0.47 & 1.00 & & & & & & & & & & & & & & & \\
\hline BD & 0.28 & 0.20 & -0.38 & 1.00 & & & & & & & & & & & & & & \\
\hline TP & 0.17 & 0.21 & 0.29 & $-0.97 * *$ & 1.00 & & & & & & & & & & & & & \\
\hline $\mathrm{pH}$ & -0.38 & $-0.62 *$ & $0.74^{\star \star *}$ & 0.39 & -0.29 & 1.00 & & & & & & & & & & & & \\
\hline EC & -0.29 & -0.14 & 0.35 & -0.22 & 0.25 & -0.05 & 1.00 & & & & & & & & & & & \\
\hline OM & -0.23 & $0.69 * \approx$ & 0.24 & -0.34 & 0.31 & -0.40 & -0.12 & 1.00 & & & & & & & & & & \\
\hline $\mathrm{TN}$ & -0.15 & $0.64^{\star \star *}$ & -0.29 & -0.45 & 0.42 & -0.35 & -0.23 & $0.95^{* \pi}$ & 1.00 & & & & & & & & & \\
\hline $\mathrm{C}: \mathrm{N}$ & 0.45 & -0.33 & -0.19 & 0.02 & 0.01 & 0.21 & -0.43 & $0.60^{*}$ & $-0.53 *$ & 1.00 & & & & & & & & \\
\hline Av.P & $-0.73 * *$ & -0.16 & $0.75^{\star \star}$ & 0.39 & -0.28 & 0.53 * & 0.09 & -0.21 & -0.23 & -0.02 & 1.00 & & & & & & & \\
\hline $\mathrm{Na}^{+}$ & -0.23 & -0.07 & 0.25 & -0.21 & 0.25 & 0.42 & -0.24 & 0.13 & 0.36 & -0.08 & 0.19 & 1.00 & & & & & & \\
\hline $\mathbf{K}^{+}$ & 0.22 & 0.01 & -0.20 & -0.39 & 0.36 & -0.34 & $0.62^{*}$ & -0.09 & -0.12 & -0.26 & -0.07 & -0.29 & 1.00 & & & & & \\
\hline $\mathrm{Mg}^{2+}$ & -0.19 & -0.14 & 0.27 & 0.01 & 0.03 & 0.23 & -0.08 & 0.10 & 0.12 & -0.10 & 0.05 & 0.34 & -0.31 & 1.00 & & & & \\
\hline $\mathrm{Ca}^{2+}$ & -0.15 & -0.15 & 0.23 & -0.10 & 0.21 & 0.45 & -0.34 & -0.01 & 0.13 & 0.29 & 0.16 & $0.57^{*}$ & -0.45 & $.61^{* \star}$ & 1.00 & & & \\
\hline CEC & $-0.53 *$ & -0.18 & $0.59 * \pi$ & 0.41 & 0.38 & $0.54^{*}$ & -0.12 & 0.43 & 0.32 & -0.08 & 0.30 & 0.14 & $-0.64 * \star$ & 0.01 & 0.04 & 1.00 & & \\
\hline EA & -0.49 & -0.17 & $0.55 *$ & -0.11 & 0.30 & 0.48 & 0.40 & -0.11 & -0.10 & -0.05 & 0.39 & 0.18 & -0.04 & 0.21 & 0.39 & 0.16 & 1.00 & \\
\hline PBS & 0.25 & -0.02 & -0.21 & -0.44 & 0.42 & -0.31 & $0.53 *$ & -0.08 & -0.06 & -0.24 & -0.09 & -0.12 & $0.94^{* k}$ & -0.02 & 0.20 & $0.76^{\star *}$ & -0.01 & 100 \\
\hline
\end{tabular}

*Significant at $\mathrm{P} \leq 0.05 ; * *$ significant at $\mathrm{P} \leq 0.01 ; \mathrm{BD}=$ Bulk density; $\mathrm{TP}=$ Total porosity; EC=Electrical conductivity; $\mathrm{TN}=$ Total nitrogen; $\mathrm{OM}=$ Organic matter;

Av. $\mathrm{P}=$ Available phosphorous; $\mathrm{C}: \mathrm{N}=$ Carbon to nitrogen ratio; $\mathrm{CEC}=$ Cation exchange capacity; $\mathrm{EA}=$ Exchangeable acidity; PBS $=$ Percent base saturation 


\section{References}

Abay, A., Sheleme, B., 2012. Characterization of soils at Angacha district in southern Ethiopia. Journal of Biology, Agriculture and Healthcare 2(1): 6-16.

Alem, H., Kibebew, K., Heluf, G., 2015. Characterization and classification of soils of Kabe Subwatershed in South Wollo Zone, Northeastern Ethiopia. African Journal of Soil Science 3(7): 134-146.

Ashenafi, A., Abayneh, E., Sheleme, B., 2010. Characterizing soils of Delbo Wegene watershed, Wolaita Zone, Southern Ethiopia for planning appropriate land management. Journal of Soil Science and Environmental Management 1 (8): 184-199.

Assen, Y., Yilma, S., 2010. Characteristics and classification of the soils of gonde micro- catchment, Arsi highlands, Ethiopia. Ethiopian Journal of Science 33(2): 101-116.

Black, C.A., 1965. Methods of soil analysis. Part 1 Physical and mineralogical properties, American Society of Agronomy, No:9. Madison, WI, USA.

Bouyoucous, G., 1962. Hydrometer method improvement for making particle size analysis of soils.Agronomy Journal.54: 179-186.

Buol, S.W., Southard, R.J., Graham, R.C., McDaniel, P.A., 2011. Soil Genesis and Classification, 6th ed. John Wiley and Sons Ltd, UK. 543p.

Chapman, H., 1965. Cation exchange capacity.In: Black, C., Ensminger, L. and Clark,F. (eds). Methods of soil analysis. American Society of Agronomy 9: 891-901.

Chaudhari, P.R., Ahire, D.V., Ahire, V.D., Chkravarty, M., Maity, S., 2013. Soil bulk density as related to soil texture, organic matter content and available total nutrients of Coimbatore soil. International Journal of Scientific and Research Publications 3(2): 1-8.

Daniel, A., Tefera, T., 2016.Characterization and classification of soils of Aba-Midan Sub Watershed in Bambasi Wereda, West Ethiopia. International Journal of Scientific and Research Publications 6(6): 390399.

Dent, D., Young, A., 1981.Soil survey and land evaluation. Allen and Unwin Ltd. London.FAO/UNDP, 1984. Provisional soils association map of Ethiopia $(1: 2,000,000)$.

FAO, 2006. Plant Nutrition for Food Security: A guide for Integrated Nutrient Management. FAO, Fertilizer and Plant Nutrition Bullet in 16, Rome, Italy.

FAO, 2014. World Reference Base for Soil Resources 2014. International soil classification system for naming soils and creating legends for soil maps. World Soil Resources Reports No. 106. Food and Agriculture Organization of the United Nations (FAO), Rome, Italy. Available at: [access date: 08.08.2017]: http://www.fao.org/3/a-i3794e.pdf

Fekadu, E., Kibret, K., Bedadi, B.,Melese, A., 2018. Characterazation and classifacatio of soils of Yikalo Subwatershed in Lay Gayint District, Northwestern Highlands of Ethiop. Eurasian Journal of Soil Science 7(2):151-166.

Gupta, P., 2004. Soil, plant, water and fertilizer analysis.Shyam Printing Press, Agrobios, India. 438p.

Havlin, J., Beaton, J., Tisdale, S., Nelson, W., 1999. Soil fertility and fertilizers. Prentice Hall, New Jersely. pp. 345-355.

Hartemink, A. E., Lowery, B., Wacker, C., 2012. Soil maps of Wisconsin. Geoderma 189-190: 451-461

Hazelton, P., Murphy, B., 2007. Interpreting soil test results.2nd ed. CSIRO Publisher. 52p.

Jackson, M.L., 1967. Soil Chemical Analysis. Prentice Hall of India Pvt. Ltd., New Delhi. 498p.

Kebede, M., Shimbir,T., Kasa, G., Abera, D., Girma, T., 2017. Description, characterization and classification of themajor soils in Jinka Agricultural Research Center,South Western Ethiopia. Journal of Soil Science and Environmental Management 8(3): 61-69.

Kiflu, A., Beyene, Sh., 2013. Effects of different land use systems on soil physical and chemical properties in Sodo Zuria Woreda of Wolaita zone Southern Ethiopia. Journal of Soil Science and Environment Management 4(5): 100-107.

Kiflu A., Beyene Sh., Jeff S. 2016. Characterization of problem soils in and around the south central Ethiopian Rift Valley. Journal of Soil Science and environmental Management 7(11): 191-203.

Landon, J., 1991. Booker tropical soil manual: A handbook for soil survey and Agricultural landscape position. International Journal of Soil Science.2 (2): 128-134.

Liu, X., He, Y., Zhang, H., Schroder, J., Zhou, J. and Zhang, Z., 2010. Impact of land use and soil fertility on distributions of soil aggregate fractions and some nutrients. Pedosphere. 20(5): 666-673.

LWAO (Legambo Woreda Agricultural Office), 2019. Annual reported data on rural land use and management systems. Unpublished document. Akesta, Ethiopia.

McLean, E.O., 1965. Aluminum Methods of Soil Analysis.Agron. No.9. Part II. Am.Soc.Agron, Madison, Wisconsin. USA. pp. 978-998.

Mekonnen, G., 2015. Characterization of agricultural soils in cascape intervention woredas of Amhara region. BDU-CASCAPE Working Paper 12. 
Melese, A., Gebrekidan, H., Yli-Halla, M., Yitaferu, B., 2015. Phosphorus status, inorganic phosphorus forms, and other physicochemical properties of acid soils of Farta District, Northwestern Highlands of Ethiopia. Applied and Environmental Soil Science.11 pp. http://dx.doi.org/10.1155/2015/748390.

Munsell Soil Colour Chart, 1994. Revised edition Macbeth Division of Kollmorgen Corporation, Baltimore, Maryland.Munsell Soil Colour Company Inc. Baltimore 18, Maryland, USA.

Nahusenay, A., Kibebew, K., Heluf, G., Abayneh, E., 2014. Characterization and classification of soils along the toposequence at the Wadla Delanta Massif, north central highlands of Ethiopia. Journal of Ecology and the Natural Environment 6(9): 304-320.

Obasi, N., Osujieke, N., Imadojemu,E., Ezend, E., 2015. Characterization and Classification of soils along Otamiri Watershed in Umuagwo, Southeastern Nigeria. FUTO Journal Series 1(2): 60-68.

Olsen, S.R., Watenabe, V.C., Dean, L.A., 1954. Estimate of available phosphorous in soil by extraction with sodium bicarbonate. USDA Circular. No. 939. USA.

Papiernik, S., Lindstrom, M., Malo, D. and Lobb, D., 2007. Characterization of soil profiles in a landscape affected by long-term tillage. Soil and Tillage Research 93: 335-345.

Pulakeshi, H.B., Patil, P.L., Dasog, G.S., 2014. Characterization and classification of soil resources derived from chlorite schist in northern transition zone of Karnataka.Karnataka Journal of Agricultural Science 27(1): 14-21.

Rowell, D., 1994. Soil science: Methods and applications. Longman Limited. England. 350p.

SAS (Statistical Analysis System), 2013.SAS Institute Inc. SAS/STAT 9.4 User's guide. Cary, NC, SAS Institute, USA, 2008.

Schoonover, J.E., Crim, J.F., 2015. An introduction to soil concepts and the role of soils in watershed management.Journal of Contemporary Water Research and Education 154(1): 21-47.

Shimeles, D., Mohamed, A., Abayney, E., 2007. Characteristics and classification of the soils of Tenocha Wenchacher Micro catchment, South west Shewa, Ethiopia. Ethiopian Journal of Natural Resources 9 (1): 37- 62.

Tefera, M., Chernet, T., Harro, W., 1996. Explanation on geological map of Ethiopia a 1:2,000,000 scale. Bulletin No 3, Addis Ababa, Ethiopia, pp 2-64.

Tekalign, T., 1991. Soil, plant, water, fertilizer, animal manure and compost analysis. Working Document No. 13. International Livestock Research Center for Africa (ILCA), Addis Ababa, Ethiopia.

Tena, W., Beyene, Sh., 2011. Identification of growth limiting nutrient(s) in Alfisols: Soil Physicochemical properties, nutrient concentrations and biomass yield of maize. American Journal of Plant Nutrition and Fertilization Technology 1(1): 23-35.

Tufa, M., Melese, A., Tena, W., 2019. Effects of land Use Types on Selected Soil Physical and Chemical Properties, The case of Kuyu district, Ethiopia. Eurasian Journal of Soil Science 8(2): 94-109.

Ukut, A., Akpan, U., Udoh, B., 2014. Characterization and classification of soils in steep sided hills and sharpcrested ridges of AkwaIbom State, Nigeria. Net Journal of Agricultural Science 2(2): 50-57.

USDA, 2008. Bulk density. United States Department of Agriculture (USDA), Natural Resources Conservation Service. Available at [Access date: 17.05.2018]:

Van-Reeuwijk, L., 1992. Procedures for Soil Analysis (3rd ed.), International Soil Reference and Information Center (ISRIC). Wageningen. The Netherlands.

Walkley, A., Black, I., 1934. An examination of Degtjareff method for determining soil organic matter and a proposed modification of the chromic acid titration method. Soil Science 37(1): 29-37.

Yitbarek,T., Beyene, Sh., Kibret, K., 2016. Characterization and Classification of Soils of Abobo Area, Western Ethiopia. Applied and Environmental Soil Science Article ID 4708235.

Yimer, F., Abdulkadir, A., 2011.The effect of cropland fallowing on soil nutrient restoration in the Bale Mountains, Ethiopia. Journal of Science and Development 1(1): 43-51.

Zeleke, T., Kibebew, K., 2009. Characterization of the existing soil management groups in terms of their Physical-hydraulic properties at Metahara sugarcane plantation.Proc. Ethiop.Con. 1:93-104. 